\title{
Natural radionuclides in bauxitic tailings (red-mud) in the Gulf of Corinth, Greece
}

\author{
G. Papatheodorou ${ }^{1}$, H. Papaefthymiou ${ }^{2}$, A. Maratou ${ }^{1}$ and G. Ferentinos ${ }^{1}$ \\ ${ }^{1}$ Department of Geology, University of Patras, Patras 26500 , Greece \\ ${ }^{2}$ Department of Chemistry, University of Patras, Patras 26500 , Greece
}

\begin{abstract}
An aluminum processing plant, which is located at the Antikyra Bay, at the northern margin of Corinth Gulf, is producing a high radioactive contamination in the marine environment, due to the discharge of bauxitic red mud tailings. The levels and the distribution of ${ }^{238} \mathrm{U},{ }^{232} \mathrm{Th},{ }^{226} \mathrm{Ra},{ }^{40} \mathrm{~K}$ and ${ }^{137} \mathrm{Cs}$ in marine sediments of the area have been determined. The results indicate that the seafloor of Antikyra bay and the basin of Gulf of Corinth are highly contaminated with ${ }^{238} \mathrm{U},{ }^{232} \mathrm{Th}$ and ${ }^{226} \mathrm{Ra}$. On the contrary, the red mud tailings induce depletion to the ${ }^{40} \mathrm{~K}$ and ${ }^{137} \mathrm{Cs}$ concentrations in the area.
\end{abstract}

\section{INTRODUCTION}

Natural and man-made radionuclides in the marine environment have various origins and sources. The major source of natural radionuclides is the weathering of terrestrial minerals and rocks, which results in enhanced levels of ${ }^{40} \mathrm{~K},{ }^{87} \mathrm{Rb},{ }^{232} \mathrm{Th},{ }^{235} \mathrm{U}$ and ${ }^{238} \mathrm{U} .{ }^{232} \mathrm{Th},{ }^{235} \mathrm{U}$ and ${ }^{238} \mathrm{U}$ decay naturally and produce radium, radon, polonium and lead. The naturally occurring radionuclides besides the above mentioned natural processes can be discharged into the marine environment through various industrial activities. Natural radionuclides can be discharged into the marine environment by: (i) the fertilizer industry, during the production of phosphoric acid, (ii) the offshore oil and natural gas production and (iii) the mining of ores, during the production of titanium dioxide; non-ferrous metals and rare earths and (iv) the aluminum during the processing of bauxite. Although, there is a considerable body of literature on the radiological impact on marine environments by the phosphate production and offshore oil/gas production, there is no any data regarding the impact of the bauxite tailings into it. The production of aluminum from bauxites can be considered as an important source of natural radionuclides input into the marine environment because bauxites usually contain significant amounts of uranium and thorium as a result of their formation by weathering of igneous, metamorphic or sedimentary rocks, followed by sedimentation and diagenesis [1]. Furthermore during the production of aluminum, the uranium and thorium concentration increases in the bauxitic tailings which are usually called "red mud". The discharge of red mud tailings into the marine environment through deep-sea disposal systems is a common technique for aluminum industry; therefore it is of importance to study the level of radiological contamination they cause in the marine environment.

For this purpose the aluminum processing plant ALUMINIO HELLAS in Greece was chosen which discharges bauxitic red mud tailings into Antikyra bay, in the northern margin of Corinth Gulf (Fig.1). The discharged red mud tailings have resulted in the formation of a surface layer which covers the seafloor of Antikyra bay as well as the basin of Corinth Gulf at a distance up to $17 \mathrm{~km}$ from the source [2-4]. A multidisciplinary environmental survey was carried out in 1994-95, in Antikyra bay and in the basin of Corinth Gulf to study (i) the dispersion and transport mechanism of red mud on the seafloor and (ii) the concentration of heavy metals and the radioactive composition of red mud deposits. In this paper the levels of radiological contamination in the red mud tailings and the surrounding natural sediments in Antikyra Bay for the natural radionuclides ${ }^{238} \mathrm{U},{ }^{232} \mathrm{Th},{ }^{226} \mathrm{Ra}$ and ${ }^{40} \mathrm{~K}$ and of the anthropogenic origin ${ }^{137} \mathrm{Cs}$, are presented. 


\section{DISPERSION OF BAUXITIC RED-MUD TAILINGS IN THE ANTIKYRA BAY AND THE BASIN OF CORINTH GULF}

The red mud tailings are discharged by "ALUMINIO HELLAS" plant, through three $2 \mathrm{~km}$ long pipelines at a water depth of about 100m, in Antikyra Bay (Fig. 1). The seafloor of Antikyra Bay is almost horizontal and dips gently southwards to a depth of about $300 \mathrm{~m}$ to a shelfbreak. The slope extends from 300 to $750 \mathrm{~m}$ water depth, having an average gradient of $5^{\circ}$ and is dissected by submarine canyons and channels (Fig. 1)[2-4]. The seafloor of the basin under the $750 \mathrm{~m}$ isobath is flat (Fig.1).

At the mouth of pipelines, the discharged red mud tailings have formed three oval shaped mounds of maximum thickness of about $24 \mathrm{~m}$. These mounds thin out radially forming a common depositional lobe (Fig 1). This red mud depositional lobe, whose thickness is more than $1 \mathrm{~m}$, covers an area of about $5 \mathrm{~km}^{2}$ on the seafloor of Antikyra bay (Fig. 1)[2-4]. Around the depositional lobe, the seafloor is covered by a reddish coloured layer, which indicates that the red mud has been mixed with natural sediments (Fig 1). This area covers $12 \mathrm{~km}^{2}$ on the seafloor of Antikyra bay (Fig. 1). In Antikyra bay and at a water depth less than $60 \mathrm{~m}$, the surface sediments appear a pinkish colour which is the result of the soaking of natural coarse-grained sediments by red mud. This area is of about $27 \mathrm{~km}^{2}$ (Fig. 1). The red mud lobe is affected by slumps which gradually are transformed to low-viscosity flows and finally to turbidity currents. The red mud turbidity currents move downslope and form thin-bedded red mud layers on the basin seafloor. These red mud layers are sometimes found to be overlain by thin layers of natural mud or by other red mud layers. Papatheodorou et al [4] suggest that in total seven red mud turbidity current events were deposited over a period of 14 years (1970-1984) while the layers of natural sediments which are intercalated with the red mud layers in the basin were also the result of turbidity currents. The successive red mud layers in the basin of Corinth Gulf cover an area of about $190 \mathrm{~km}^{2}$. [2-4].

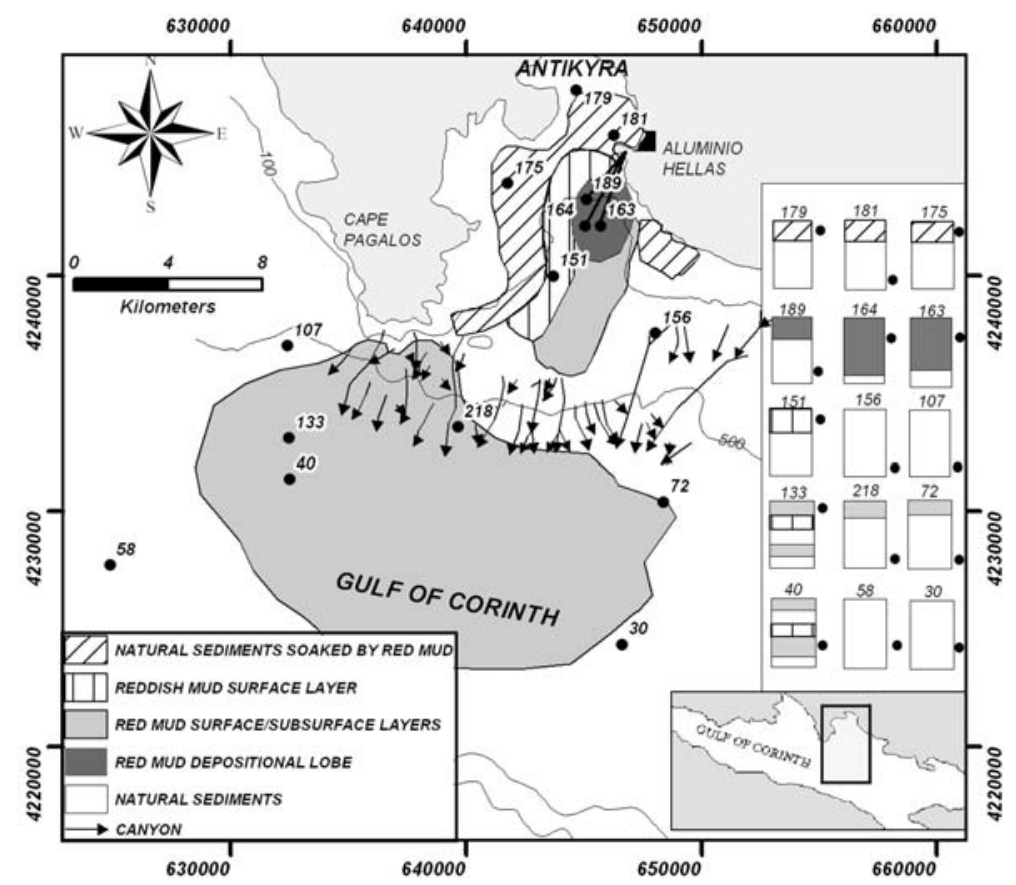

Figure 1. Bathymetric map of the study area showing the location of the sampling stations and the lateral distribution of the bauxite "red - mud" tailings over the shelf (Antikyra Bay), slope and basin floor. Arrow traces the channels over the slope. Inserts show: (i) the location of the study area in the Gulf of Corinth and (ii) the lithological description of the sediment cores; the solid dots indicate the sediment sections were taken for radionuclide determination. 


\section{METHODS}

Fifteen sediment cores were collected using a Day grab and a $3 \mathrm{~m}$ long gravity corer. The sampling points and the lateral distribution of bauxitic red mud tailings are presented in Fig.1. Three cores $(163,164,189)$ were collected from the red mud depositional lobe; one (151) from the reddish mud area; three $(175,179,181)$ from the area where the natural sediments are soaked in red mud; two $(40,133)$ from the red mud layers in the basin of Corinth Gulf and five cores $(30,58,72,107,156)$ from the surrounding natural sediments (Fig. 1). Fifteen subsamples of red mud and natural sediments as well as two bauxite (B1, B2) samples were radiological analysed.

All the sediment samples were air-dried, crushed to fine powder and homogenized. The homogenized samples were dried at $105{ }^{\circ} \mathrm{C}$ to constant weight, packed in cylindrical containers of 68 $\mathrm{mm}$ diameter and $20 \mathrm{~mm}$ height, weighed, hermetically sealed and stored for more than four weeks prior to counting to ensure that secular equilibrium would be achieved between ${ }^{226} \mathrm{Ra}$ and its short lived daughter products. The activities of the samples were determined by direct $\gamma$-ray spectroscopy.

\section{RESULT AND DISCUSSION}

The ${ }^{238} \mathrm{U},{ }^{232} \mathrm{Th},{ }^{226} \mathrm{Ra},{ }^{40} \mathrm{~K}$ and ${ }^{137} \mathrm{Cs}$ activities of red mud deposits and natural sediments in Antikyra Bay and the basin of the Corinth Gulf are shown in Table 1. These same activities are shown in the histograms of Figure 2. Table 2 compares the activity concentrations of ${ }^{238} \mathrm{U},{ }^{232} \mathrm{Th},{ }^{226} \mathrm{Ra}$ and ${ }^{40} \mathrm{~K}$ in red mud deposits and natural sediments of the present study with those by other investigations in different locations in Greece and in the world.

The study of natural radionuclides activity histograms showed a clear inverse relationship between ${ }^{238} \mathrm{U}-{ }^{232} \mathrm{Th}-{ }^{226} \mathrm{Ra}$ group and ${ }^{40} \mathrm{~K} .{ }^{238} \mathrm{U},{ }^{232} \mathrm{Th}$ and ${ }^{226} \mathrm{Ra}$ correlate positively with one another and exhibit similar areal variations, as is indicated by the same distribution pattern in the histograms (Fig. 2).

Table 1. Activity concentration of ${ }^{238} \mathrm{U},{ }^{226} \mathrm{Ra},{ }^{232} \mathrm{Th},{ }^{40} \mathrm{~K}$ and ${ }^{137} \mathrm{Cs}$ in the red mud samples and the natural sediments of Corinth Gulf. (B1 and B2: bauxite samples) $\left(\mathrm{Bq} \mathrm{kg}^{-1}\right.$ d.w. $\left.\pm 1 \mathrm{~s}_{\mathrm{tot}}{ }^{*}\right)$.

\begin{tabular}{|c|c|c|c|c|c|}
\hline $\begin{array}{c}\text { Sample } \\
\text { code }\end{array}$ & ${ }^{238} \mathrm{U}$ & ${ }^{226} \mathrm{Ra}$ & ${ }^{232} \mathrm{Th}$ & ${ }^{40} \mathrm{~K}$ & ${ }^{137} \mathrm{Cs}$ \\
\hline 30 & $29.8 \pm 9.0$ & $26.5 \pm 0.7$ & $26.1 \pm 0.8$ & $480.0 \pm 18.0$ & $3.3 \pm 0.4$ \\
\hline 40 & $112.7 \pm 16.7$ & $65.6 \pm 1.0$ & $112.8 \pm 2.2$ & $405.6 \pm 22.4$ & $4.3 \pm 0.5$ \\
\hline 58 & $19.7 \pm 5.5$ & $25.8 \pm 0.6$ & $21.0 \pm 0.6$ & $355.6 \pm 13.7$ & $3.0 \pm 0.4$ \\
\hline 72 & $47.7 \pm 9.3$ & $27.0 \pm 0.7$ & $25.0 \pm 0.8$ & $503.8 \pm 19.3$ & $0.7 \pm 0.2$ \\
\hline 107 & $25.7 \pm 8.2$ & $28.8 \pm 2.9$ & $29.3 \pm 0.8$ & $539.9 \pm 20.0$ & $3.3 \pm 0.4$ \\
\hline 133 & $67.6 \pm 12.4$ & $49.3 \pm 3.1$ & $82.7 \pm 1.5$ & $264.0 \pm 13.7$ & $4.7 \pm 0.6$ \\
\hline 151 & $29.9 \pm 10.0$ & $34.5 \pm 0.9$ & $50.7 \pm 1.3$ & $444.3 \pm 17.1$ & $5.7 \pm 0.6$ \\
\hline 156 & $13.1 \pm 7.3$ & $35.2 \pm 0.9$ & $31.2 \pm 1.2$ & $499.0 \pm 24.0$ & $6.8 \pm 0.8$ \\
\hline 163 & $399.8 \pm 28.1$ & $185.2 \pm 9.2$ & $412.0 \pm 5.0$ & $71.5 \pm 15.3$ & $1.5 \pm 0.3$ \\
\hline 164 & $250.4 \pm 18.0$ & $167.6 \pm 2.3$ & $399.4 \pm 1.1$ & $82.3 \pm 16.1$ & $\mathrm{ND}$ \\
\hline 175 & $36.6 \pm 7.8$ & $16.2 \pm 0.5$ & $15.9 \pm 3.3$ & $223.5 \pm 12.3$ & $3.1 \pm 0.4$ \\
\hline 179 & $43.1 \pm 8.2$ & $16.2 \pm 0.4$ & $17.5 \pm 0.8$ & $246.7 \pm 15.1$ & $4.1 \pm 0.5$ \\
\hline 181 & $36.6 \pm 9.0$ & $22.2 \pm 0.8$ & $28.0 \pm 0.7$ & $145.3 \pm 12.6$ & $4.2 \pm 0.5$ \\
\hline 189 & $51.9 \pm 11.5$ & $12.9 \pm 0.8$ & $15.1 \pm 0.7$ & $160.1 \pm 15.7$ & $\mathrm{ND}$ \\
\hline 218 & $27.7 \pm 9.2$ & $17.0 \pm 0.8$ & $16.0 \pm 0.4$ & $359.6 \pm 16.4$ & $\mathrm{ND}$ \\
\hline B1 & $247.5 \pm 19.0$ & $150.0 \pm 1.2$ & $205.0 \pm 2.2$ & $28.3 \pm 7.6$ & $\mathrm{ND}$ \\
\hline B2 & $143.1 \pm 13.5$ & $73.7 \pm 0.8$ & $226.4 \pm 3.2$ & $\mathrm{ND}$ & $\mathrm{ND}$ \\
\hline
\end{tabular}

ND: Not detected

stot $^{*}$ : Combined standard uncertainty. 
The highest ${ }^{238} \mathrm{U},{ }^{232} \mathrm{Th}$ and ${ }^{226} \mathrm{Ra}$ activities were measured in the red mud samples while the highest ${ }^{40} \mathrm{~K}$ activity was observed in the natural sediments. This observation suggests that the distribution patterns of the natural radionuclides in the area are highly affected by the distribution of the red mud deposits. The ${ }^{238} \mathrm{U},{ }^{232} \mathrm{Th}$ and ${ }^{226} \mathrm{Ra}$ obtained low activities in the natural sediments of the area, ranging from 13.1 to $51.9 \mathrm{~Bq} \mathrm{~kg}^{-1}, 15.1$ to $31.2 \mathrm{~Bq} \mathrm{~kg}^{-1}$ and 12.9 to $35.2 \mathrm{~Bq} \mathrm{~kg}^{-1}$, respectively. These values are comparable with those found in uncontaminated sediments of the Aegean Sea (29-110, 4-106 and $\left.4-159 \mathrm{~Bq} \mathrm{~kg}^{-1}\right)[5,6]$ and in others places in the world. In addition, the mean activities of ${ }^{238} \mathrm{U}$ and ${ }^{232} \mathrm{Th}\left(31.9 \mathrm{~Bq} \mathrm{~kg}^{-1}, 24.13 \mathrm{~Bq} \mathrm{~kg}^{-1}\right)$ in the natural sediments of the surveyed area, are comparable to those of the world average $\left(25 \mathrm{~Bq} \mathrm{~kg}^{-1}, 25 \mathrm{~Bq} \mathrm{~kg}^{-1}\right)$ as reported by UNSCEAR [7] (Table 1 and 2).

Table 2. The mean activity concentrates in $\mathrm{Bq} \mathrm{kg}^{-1}$ and minimum and maximum values of the primordial natural radionuclides for different countries.

\begin{tabular}{|c|c|c|c|c|c|}
\hline \multirow{2}{*}{ Country } & \multicolumn{4}{|c|}{ Mean activity concentration in $\mathrm{Bq} \mathrm{kg}^{-1}$ (range) } & \multirow{2}{*}{ References } \\
\hline & ${ }^{238} \mathrm{U}$ & ${ }^{232} \mathrm{Th}$ & ${ }^{226} \mathrm{Ra}$ & ${ }^{40} \mathrm{~K}$ & \\
\hline $\begin{array}{l}\text { Greece - } \\
\text { Cyclades }\end{array}$ & $67(29-110)$ & $31(4-106)$ & $26(7-159)$ & $666(189-1214)$ & {$[5]$} \\
\hline $\begin{array}{c}\text { Other Greek } \\
\text { areas }\end{array}$ & & $13(4-47)$ & $15(4-50)$ & $173(47-627)$ & {$[6]$} \\
\hline $\begin{array}{c}\text { Greece - Milos } \\
\text { island }\end{array}$ & & $75(19-152)$ & $70(16-119)$ & $890(158-3893)$ & {$[5]$} \\
\hline Black Sea & & & & $(37-580)$ & {$[12]$} \\
\hline $\begin{array}{c}\text { Spain - Bay of } \\
\text { Gadiz (harbours) }\end{array}$ & & $300(150-470)$ & $8.6(5.0-16.0)$ & & {$[13]$} \\
\hline $\begin{array}{l}\text { S.W Spain } \\
\text { (estuaries) }\end{array}$ & $327(103-413)$ & $52.2(17.6-67.5)$ & $179(49-225)$ & $360(235-402)$ & {$[14]$} \\
\hline Irish Sea & $6.8(1.8-24.7)$ & $10.5(4.1-22.0)$ & & & {$[15]$} \\
\hline $\begin{array}{c}\text { Egypt - Red Sea } \\
\text { (harbours) }\end{array}$ & $38.6(3-168)$ & $31.4(5.5-91)$ & & & {$[16]$} \\
\hline Algeria & & & $77(27-133)$ & $403(184-632)$ & {$[17]$} \\
\hline Kuwait & $40(4.4-115)$ & $6.8(1.6-17)$ & $39.1(8.1-72)$ & $\begin{array}{c}247.4 \\
(40.5-492)\end{array}$ & [18] \\
\hline Cuba & $12(7-15)$ & $3.2(0.9-5.9)$ & & $312(235-402)$ & [19] \\
\hline World Average & $25(10-50)$ & $25(7-50)$ & & $370(100-700)$ & [7] \\
\hline $\begin{array}{c}\text { Greece - Corinth } \\
\text { Gulf }\end{array}$ & $\begin{array}{c}79.49 \\
(13.1-399.8)\end{array}$ & $\begin{array}{c}85.51 \\
(15.1-412.0)\end{array}$ & $\begin{array}{c}48.67 \\
(12.9-185.2)\end{array}$ & $\begin{array}{c}318.75 \\
(28.3-539.9)\end{array}$ & $\begin{array}{l}\text { Present } \\
\text { study }\end{array}$ \\
\hline
\end{tabular}
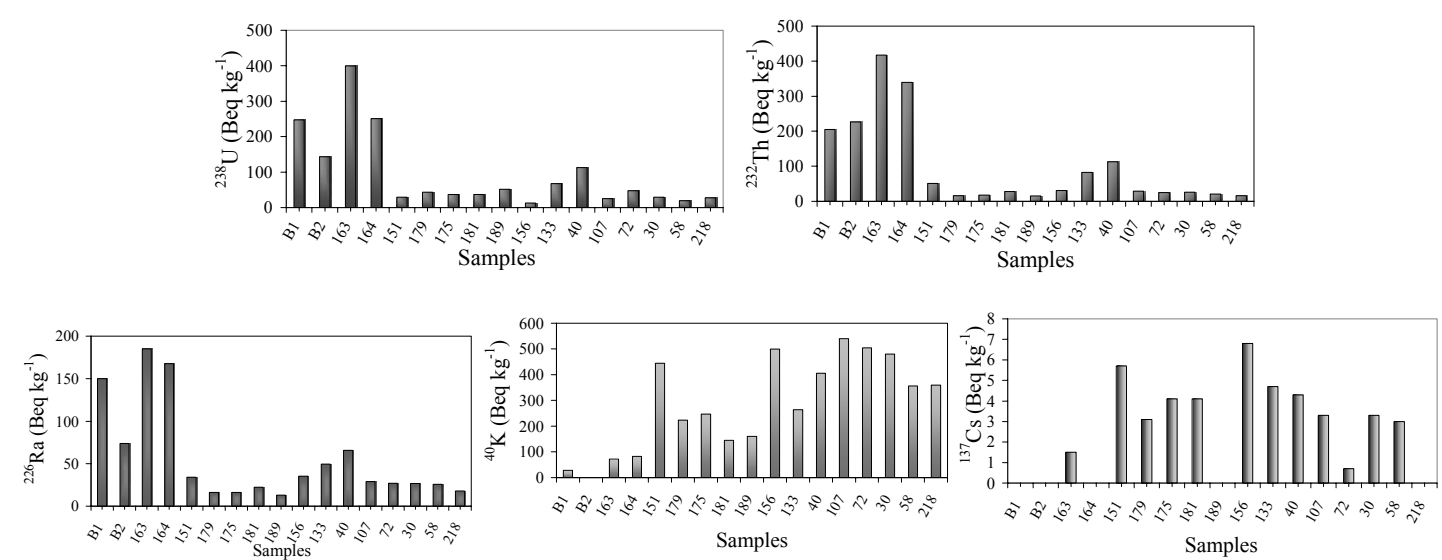

Figure 2. Histograms showing the activities of $\mathrm{U}, \mathrm{Th}, \mathrm{Ra}, \mathrm{K}$ and $\mathrm{Cs}$ in the red mud samples and the natural sediments of the study area. (B1 and B2: bauxite samples). 
The highest measured ${ }^{238} \mathrm{U},{ }^{232} \mathrm{Th}$ and ${ }^{226} \mathrm{Ra}$ content on the surveyed area, was detected in the red mud depositional lobe at the mouth of the pipelines (samples 163 and 164) and was found to be in the range of $250.4-399.8 \mathrm{~Bq} \mathrm{~kg}^{-1}, 399.4-417.2 \mathrm{~Bq} \mathrm{~kg}^{-1}$ and $167.6-185.2 \mathrm{~Bq} \mathrm{~kg}^{-1}$, respectively (Table 1). These values are significantly higher than those of bauxitic material prior to the treatment during the Bauer process, suggesting a ${ }^{238} \mathrm{U},{ }^{232} \mathrm{Th}$ and ${ }^{226} \mathrm{Ra}$ red mud enrichment. The degree of enrichment of ${ }^{238} \mathrm{U},{ }^{232} \mathrm{Th}$ and ${ }^{226} \mathrm{Ra}$ ranges from 1.1 to 2.8 and decreases in the following order: ${ }^{232} \mathrm{Th}>{ }^{238} \mathrm{U}>{ }^{226} \mathrm{Ra}$. These results are in good agreement with the findings of von Philipsborn and Kuhnast [1], who analyzed four industrially used bauxites and the red mud tailings associated with them. In that study the reported red-mud radionuclides concentrations were twice the values for bauxite [1].

The high values of ${ }^{238} \mathrm{U},{ }^{232} \mathrm{Th}$ and ${ }^{226} \mathrm{Ra}$ in the red mud depositional lobe are out of range of those cited in literature. In seabed sediments from contaminated and non contaminated areas around the world, have measured activities lower to the values found in the red mud depositional lobe (Table 2). Moreover, the observed values of ${ }^{238} \mathrm{U}_{-}{ }^{232} \mathrm{Th}_{-}{ }^{226} \mathrm{Ra}$ group at the main body of the red mud represent the maxima of the reported range of values (29-110 Bq kg Aegean and Ionian seas [5]. In addition, these values are even higher than those reported for mining areas (aluminum silicate and iron sulphate) of Milos Island which is located in the volcanic arc of the Aegean Sea [5]. It should be noted that the volcanic areas are characterized by enhanced concentrations of natural radionuclides [8].

The mean activity of ${ }^{238} \mathrm{U}\left(325.1 \mathrm{~Bq} \mathrm{~kg}^{-1}\right)$ for depositional lobe is about 13 times higher than that of the world average $\left(25 \mathrm{~Bq} \mathrm{~kg}^{-1}\right)$, whereas ${ }^{232} \mathrm{Th}$ activity in the same area $\left(408.3 \mathrm{~Bq} \mathrm{~kg}^{-1}\right)$ in the present study is over 16 times higher than that of the world average $\left(25 \mathrm{~Bq} \mathrm{~kg}^{-1}\right)$ as reported by UNSCEAR [7] (Tables 1 and 2). The above suggest that there is a strong contamination with ${ }^{238} \mathrm{U}$, ${ }^{232} \mathrm{Th}$ and ${ }^{226} \mathrm{Ra}$ in the part of Antikyra bay due to the red mud discharges. This conclusion can be also confirmed by studying the degrees of enrichment of natural radionuclides at the red mud depositional lobe. ${ }^{238} \mathrm{U},{ }^{232} \mathrm{Th}$ and ${ }^{226} \mathrm{Ra}$ are highly enriched in the red mud main lobe relative to underlying natural sediments. Their degrees of enrichment ranging from 7.4 to $13.3,16.1$ to 16.8 and 7.2 to 7.9 for ${ }^{238} \mathrm{U}$, ${ }^{232} \mathrm{Th}$ and ${ }^{226} \mathrm{Ra}$ respectively, and are comparable to those obtained in highly radioactive contaminated estuarine sediments, due to fertilizer plants [9]. If we assume that the observed mean ${ }^{238} \mathrm{U},{ }^{232} \mathrm{Th}$ and ${ }^{226} \mathrm{Ra}$ activities are almost constant all over the depositional lobe, then the area of highly radioactive contamination as a consequence of red mud tailing disposal system of the aluminum processing plant, extends for about $5 \mathrm{~km}^{2}$ (Fig. 1). This area is located about $1 \mathrm{~km}$ away from the shoreline at a water depth ranging from 75 to $100 \mathrm{~m}$, in the eastern part of Antikyra bay (Fig. 1).

Around the main depositional lobe of red mud, the seafloor is covered by a surface layer of reddish mud (Fig. 1). Sample 151 which was collected from this area has shown that the ${ }^{232} \mathrm{Th}$ activity reaches about twice the values commonly assigned as the world average, and the ${ }^{238} \mathrm{U}$ activity is comparable to the world average (Table 1 and 2). The same trends are observed between reddish mud radionuclides activities and those of the underlying natural sediments (Table 1).

At the periphery of the previous zone, and at water depths less than $60 \mathrm{~m}$, the seafloor consists of coarse-grained sediments soaked by the red mud as indicated by the pale pinky colour. The activities for ${ }^{238} \mathrm{U},{ }^{232} \mathrm{Th}$ and ${ }^{226} \mathrm{Ra}$ measured at the samples (179 and 175) collected from this area are lower than those of world average and the natural sediments of Antikyra bay (Table 1 and 2). This suggests that there is no contamination with ${ }^{238} \mathrm{U},{ }^{232} \mathrm{Th}$ and ${ }^{226} \mathrm{Ra}$ at the shallow waters $(<60 \mathrm{~m})$ of Antikyra Bay. The significant lower activities of ${ }^{232} \mathrm{Th}$ and ${ }^{226} \mathrm{Ra}\left(16.7 \mathrm{~Bq} \mathrm{~kg}^{-1}\right.$ and $\left.16.2 \mathrm{~Bq} \mathrm{~kg}{ }^{-1}\right)$ in the sediments soaked by red mud compared to the natural sediments of Antikyra bay and those from the Corinth Gulf basin, may reflect the coarse-grained texture of the former. It is well known that the radionuclides concentrations are influenced by the granulometric composition. Radionuclide activities decrease when grain size of the sediments increases [10].

High ${ }^{238} \mathrm{U},{ }^{232} \mathrm{Th}$ and ${ }^{226} \mathrm{Ra}$ activities were also measured at the surface (sample 133) and subsurface (sample 40) red mud layers in the Corinth Gulf basin (Table 1). This is not surprising, because as mentioned before, these red mud layers represent turbidites which are formed by turbidity currents originating from the main red mud depositional lobe at the mouth of the pipelines. The enhanced ${ }^{238} \mathrm{U},{ }^{232} \mathrm{Th}$ and ${ }^{226} \mathrm{Ra}$ activities in the basin are within the range of contaminated marine sediments due to mining, industrial and harbour activities in Greece and other locations in the world 
(Table 2). The mean activities of ${ }^{238} \mathrm{U}\left(90.2 \mathrm{~Bq} \mathrm{~kg}^{-1}\right)$ and ${ }^{232} \mathrm{Th}\left(97.8 \mathrm{~Bq} \mathrm{~kg}^{-1}\right)$ in the red mud layers in the basin, are about 3.0 and 3.9 times higher than those of the world average (Table 1 and 2). This clear radioactive contamination of the basin is further supported by the high degrees of radionuclides enrichment compared to the natural underlying sediments. ${ }^{238} \mathrm{U},{ }^{232} \mathrm{Th}$ and ${ }^{226} \mathrm{Ra}$ show an enrichment factor ranging for 1.4 to 5.7 (Table 1). Taking into account that the successive red mud layers cover an area of about $190 \mathrm{~km}^{2}$ on the basin floor and assuming that the ${ }^{238} \mathrm{U},{ }^{232} \mathrm{Th}$ and ${ }^{226} \mathrm{Ra}$ activities in red mud layers are expected to be constant all over the basin, then the major part of the central of Corinth Gulf basin can be considered as radioactively contaminated due to discharged bauxitic tailings.

As outlined above, the areal distribution of ${ }^{40} \mathrm{~K}$ in the red mud deposits and the natural sediments of the surveyed area exhibits an inverse pattern compared to those of ${ }^{238} \mathrm{U},{ }^{232} \mathrm{Th}$ and ${ }^{226} \mathrm{Ra}$. The red mud depositional lobe has very low ${ }^{40} \mathrm{~K}$ activities $\left(71.5-82.3 \mathrm{~Bq} \mathrm{~kg}^{-1}\right)$. On the other hand, in the natural sediments of the area, ${ }^{40} \mathrm{~K}$ contents varied in the range of 160.1 to $539.9 \mathrm{~Bq} \mathrm{~kg}^{-1}$. This depositional pattern is affected by the low ${ }^{40} \mathrm{~K}$ activities in the bauxites, as indicated by the bauxite samples analyses (Table 1). The ${ }^{40} \mathrm{~K}$ activity is very low $\left(<30 \mathrm{~Bq} \mathrm{~kg}^{-1}\right)$ in the bauxite rocks used in the aluminum processing plant and thus the discharged red mud tailings induce a clear depletion in the ${ }^{40} \mathrm{~K}$ concentration in the sediments of the area. However the activity concentrations of ${ }^{40} \mathrm{~K}$ in the surveyed area $\left(71.5-539.9 \mathrm{~Bq} \mathrm{~kg}^{-1}\right)$ are measured to fall inside the world range (100-700 Bq kg-1) and are typical of uncontaminated marine sediments (Table 2). Therefore, the discharged red mud tailings in Antikyra bay are not identified as a potential source of ${ }^{40} \mathrm{~K}$ contamination.

Regarding anthropogenic radionuclide ${ }^{177} \mathrm{Cs}$ and considering that in the surveyed area there are neither nuclear power plants nor other direct sources; its concentration is only due to the fallout directly over the area. In the surface layers of the sediments $(0-5 \mathrm{~cm})$ the ${ }^{137} \mathrm{Cs}$ concentration varied from between 1.5 to $6.8 \mathrm{~Bq} \mathrm{~kg}^{-1}$ while in the subsurface sediments $(<5 \mathrm{~cm})$ observed a more narrow range of activity (0.7-4.3 Bq kg-1) (Table 1). Although, caesium contents are not available for the marine sediments of Corinth Gulf before and after the Chernobyl accident, Florou [11] suggests that for the Greek sub-littoral zone, the levels of ${ }^{137} \mathrm{Cs}$ varied in the range of $1-2 \mathrm{~Bq} \mathrm{~kg}^{-1}$ until 1986, within the range 4-5 $\mathrm{Bq} \mathrm{kg}^{-1}$ during 1986-87 and within 2-4 $\mathrm{Bq} \mathrm{kg}^{-1}$ for the period 1990-94. Taking into account that the sediment samples of this study collected in 1994 , the ${ }^{137} \mathrm{Cs}$ activity in the sediments of Antikyra Bay and the Corinth Gulf basin is comparable to those found by Florou [11] in other Greek coastal areas. The ${ }^{137} \mathrm{Cs}$ histogram reveals that ${ }^{137} \mathrm{Cs}$ activity are found to be minimal $\left(<1.5 \mathrm{~Bq} \mathrm{~kg}^{-1}\right)$ in the main red mud depositional lobe suggesting that the discharged red mud induces a depletion to the ${ }^{137} \mathrm{Cs}$ concentrations in the area (Fig. 2). This is expected because the bauxite material for the production of aluminum comes from underground mining and thus this material has been protected by the ${ }^{137} \mathrm{Cs}$ fallout in its source area.

\section{References}

[1] Von Philipsborn H. and Kuhnast E., Rad. Prot. Dosimetry 45 (1992) 741-743.

[2] Papatheodorou G., Unpublished PhD. Thesis, University of Patras, Greece (1991) p. 240.

[3] Papatheodorou G. Lyberis E. and Ferentinos G., Nat. Res. Research 8 (1999) 277-285.

[4] Papatheodorou G. Stefatos A. Christodoulou D. and Ferentinos G., Adv. Nat. Tech. Hazards Research 19 (2003) 459-469.

[5] Florou H. and Kritidis P., Mar. Poll. Bulletin 22 (1991) 417-419.

[6] Environmental Radioactivity Laboratory. Environmental monitoring program of the Country. N.C.S.R. "Demokritos" (1989).

[7] UNSCEAR, Effects and risk of ionizing radiation No. E88.IX.7. (1988).

[8] Forstner U. and Wittman G.T.W. Metal pollution in the Aquatic environment, Spinger-Verlag, Berlin (1979).

[9] San Miguel E.G. Bolivar J.P. and Garcia-Tenorio R., Sci Total Environ 318 (2003) 143-157.

[10] He Q. and Walling D.E., J. Environ. Radioactivity 30 (1996) 117-137. 
[11] Florou H., Unpublished PhD. Thesis, University of Athens, Greece (1992) p. 253.

[12] Strezov A. Milanov M. Mishev P. and Stoilova T., Appl. Radiat. Isot. 12 (1998) 1721-1728.

[13] Ramos-Lerate I. Barrera M. Ligero R.A. and Casas M., Rad. Prot. Dosimetry 75 (1998) 41-48.

[14] Bolivar J.P. Garcia-Tenorio R. Mas J.L. and Vaca F., Environ. Inter. 27 (2002) 639-645.

[15] McCartney M. Kershaw P.J. Allington D.J. Young A.K. Turner D., Rad. Prot. Dosimetry 45 (1992) 711-714.

[16] Sam A.K. Ahamed M.M. El Khangi F.A and El Nigumi Y.O. Radioch. Acta 88 (2000) 307-312.

[17] Noureddine A. Baggoura B. Hocini N. and Boulahdid M. Appl. Radiat. Isot 49 (1998) 1745-1748

[18] Saad H.R. and Al-Azmi D., Appl. Radiat. Isot. 56 (2002) 991-997.

[19] Hernandez C.A. Asencio M.D. Caravaca A.M. Morell E.S. and Morales R.C., Rad. Prot. Dosimetry 75 (1998) 69-70. 